\title{
Award of the Republic of Philippines v. the People's Republic of China: Legal Implications on the South China Sea Disputes
}

\author{
Thi Lan Anh Nguyen ${ }^{1}$
}

Introduction

Initiated in January 2013, after more than three years, on 12 July 2016, the Arbitral Tribunal established in accordance with Annex VII of the UN Convention on the Law of the Sea (UNCLOS) issued its final award on the case over some aspects of the South China Sea (scs) disputes between the Philippines and China. Whether one likes it or not, the South China Sea case marked the first attempt to settle the differences between the parties by peaceful means within the current rules-based order. The legal arguments of both parties to the case, the reasoning and conclusions of the arbitral tribunal carry enormous legal implications for the scs disputes. This paper will first summarise the subject matter, procedural aspects and the conclusions of the award in the case filed by the Philippines against China. It then analyses the legal implications of the award on substantive and procedural aspects of the scs disputes. With regard to the substantive aspect, the paper will examine the impacts of the award on both the sovereignty and maritime disputes in the scs. In respect of the procedural aspect, the paper will explore the contribution of the award to dispute settlement and management of the scs disputes.

\section{Summary of the scs Arbitration Awards}

The arbitration case between the Philippines and China was unilaterally initiated by the Philippines under Annex VII of UNCLOS on 19 January 2013. In its position paper dated 7 December 2014, China challenged the jurisdition of the Arbitral Tribunal. ${ }^{2}$ The Arbitral Tribunal treated China's rejection as a plea

\footnotetext{
1 The views expressed in this paper are strictly those of the author and do not necessarily reflect any official position of the Diplomatic Academy of Vietnam.

2 Available at: http://www.fmprc.gov.cn/mfa_eng/zxxx_662805/t1217147.shtml.
} 
concerning its jurisdiction and decided to bifurcate the proceedings. ${ }^{3}$ Accordingly, the first hearing was held from 7 to 13 July 2015 to address jurisdiction and admisibility. In the award on jurisdiction issued on 29 October 2015, the Tribunal concluded that it had jurisdiction over 7 among 15 submissions of the Philippines, 7 others would consider the jurisdiction and admisibility in combination with the merits and 1 submission was requested for further clarification. ${ }^{4}$ The second hearing was convened from 24 to 30 November 2015 on the merits and resulted in the final award on 12 July $2016 .{ }^{5}$

In the first award, in order to conclude on jurisdition and admissibility, the Tribunal addressed three issues, including the nature of the disputes between China and the Philippines, the procedural requirements for the Philippine submission and the limitations and exceptions under Articles 297 and 298 of UNCLOS.

Regarding the nature of the disputes, China argues that the subject-matter of the arbitration initiated by the Philippines is territorial sovereignty over several maritime features in the SCs, therefore, is beyond the scope of the dispute settlement procedure provided for under UnCLOS. ${ }^{6}$ The Tribunal denied the arguments of China and supported the submissions of the Philippines on the basis of the existence of the disputes between the two parties as a question of interpreation of unclos. Accordingly, the Tribunal held that submissions number 1 and 2 of the Philippines reflected the disagrement between the two parties on interpreting "historic rights" under UNCLOS. ${ }^{7}$ Submissions 3 to 7 constitute the differences in understanding and applying UNCLOS on the legal regime of maritime features and their maritime entitlements in the scs. ${ }^{8}$ Submissions 8 to 14 are related to the interpretation and application of UNCLOS on actitivities concerning hydrocarbon exploration, exploitation, fishery, construction at sea and marine environment protection. ${ }^{9}$ The Tribunal also elaborated that the disputes between the two parties consist of several components and the existence of disputes on territorial sovereignty will not rule out the disputes on other aspects. In this case, addressing the submissions of the

3 The fourth press release of the Arbitration, available at: https:/www.pcacases.com/web/ sendAttach/1298.

4 AwARd on JURisdiction AND Admissibility, para. 413, available at: https://www.pcaca ses.com/web/sendAttach/1506.

5 The eighth press release of the Arbitration, available at: https:/www.pcacases.com/web/ sendAttach/1521 (hereafter referred to as JuRisdiction AWARD).

6 Part Ii, Position Paper of China, 7 December 2014.

7 Paras. 164-168, Jurisdiction Award.

8 Paras. 169-172, Jurisdiction Award.

9 Paras. 173-177, Jurisdiction AWArd. 
Philippines will neither require the Tribunal to conclude on sovereignty issues, nor consolidate sovereignty claims of any parites. ${ }^{10}$ The Tribunal also rejects the assimilation between maritime entitlement and maritime delimitation. ${ }^{11}$

Concerning the procedural requirements, the Tribunal reviewed all multilateral and bilateral agreements between Philippines and China, such as the 2002 Declaration on the Conduct of Parties in the SCS (DOC), the 1976 Treaty of Amity and Cooperation (TAC), the Convention on Biological Diversity (CBD), the Convention on International Trade of Endanger Spices (CiTES), among others, and concluded that the two parties neither made any options on dispute settlement means, nor ruled out the possibility of settling their disputes under UnCLOS. ${ }^{12}$ The Tribunal also recognized that the Philippines has completed their obligations on the exchange of views..$^{13}$ The Tribunal, therefore, endorsed the right of the Philippines to submit the case before Arbitration established under Annex VII of UNCLOS.

With respect to the limitations and exceptions under Articles 297 and 298 of UNCLOS, the Tribunal adknowleged the Statement made by China in 2006 in accordance with Article 298 and concluded that submissions 4, 6 and 7 concerning legal status of maritime features and submissions $3,10,11$ and 13 concerning Scarborough, traditional fishing rights, maritime environment protection and safety of navigation were excluded from the exception of Article $298 .{ }^{14}$ Meanwhile, submissions 1 and 2 on the nine-dashed line, submission 5 on the ownership of Mischief Reef and Second Thomas Shoal, submissions 8, 9, 12 on Chinese activities conducted in the exclusive economic zone (EEZ) and continental shelf of the Philippines and submission 14 on exaggeration of the disputes contain the interelation between jurisdition and substances, thus are left to be addressed in combination in the merit hearing. ${ }^{15}$

In the merit award, the Tribunal delivered comprehensive conclusions on three major issues, namely the maritime entitlement of the nine-dashed line, legal regime of maritime features and the legality of a handful activities conducted by China in the scs.

In clarifying the maritime entitlement of the nine-dashed line, the Tribunal drew the distinction between the concepts of historic bays, historic waters,

\footnotetext{
10 Paras. 148-153, Jurisdiction Award.

11 Para. 155-157, JuRisdiction Award.

12 Paras. 212-229, 241-251, 265-296, 281-289, 299-302, 307-310, and 317-321, JURISDICTION AWARD.

13 Paras. 332-352, Jurisdiction Award.

14 Paras. 400, 401, 403, 404, 407, 408 and 410, Jurisdiction AWARD.

15 Paras. 390-396, Jurisdiction Award.
} 
historic titles and historic rights under customary international as well as under UNCLOS and concluded that historic titles in Article 298 of UNCLOS referred to claims of sovereignty over maritime areas derived from historical circumstances. ${ }^{16}$ The Tribunal also examined various official statements, legislation and conduct of China in the scs to explore the nature of maritime claims resulted from the nine-dashed line of China. The fact that China still respects the freedom of navigation of others and Chinese fishery has never been conducted exclusively in the waters within the nine-dashed line led to the Tribunal's conclusion that China neither claimed historic title, historic water, nor historic bay over the waters of the scs. What China claims is rather a constellation of historic rights short of title. ${ }^{17}$ However, as UNCLOS is currently the only systematic source of international law to distribute maritime rights and obligations to coastal States, the Tribunal concluded that China's claims to historic rights, or other sovereign rights or jurisdiction, with respect to the maritime areas of the scs encompassed by the relevant part of the ninedashed line are contrary to UNCLOS and without lawful effect to the extent that they exceed the geographic and substantive limits of China's maritime entitlements under UNCLOS. ${ }^{18}$

Concerning the legal regime of some maritime features in the scs, the Tribunal first relies on the definition provided for under Article 13 of UNCLOS, data on tidal ranges, the Schofield Report, ${ }^{19}$ nautical surveying and sailing directions to clasify maritime features into low and high tide features. As a result, the Tribunal concluded that of the nine maritime featured submitted by the Philippines, six maritime features, namely Scarborough Shoal, Cuarteron Reef, Fiery Cross Reef, Johnson Reef, McKennan Reef, and Gaven Reef (North) remain above water at high tide and are accordingly high-tide features. In their natural condition, five maritime features, namely, Hughes Reef, Gaven Reef (South), Subi Reef, Mischief Reef, and Second Thomas Shoal are exposed at low tide and submerged at high tide and are accordingly low-tide elevations. Among them, Hughes Reef lies within 12 nautical miles of the high-tide features on McKennan Reef and Sin Cowe Island, Gaven Reef (South) lies within

16 Para. 226 of the Arbitral Tribunal Award on the Merits, available at: http://www.pcacases .com/pcadocs/PH-CN\%20-\%2020160712\%20-\%20Award.pdf (hereafter referred as the Merits AWARD).

17 Para. 229, MERITS AWARD.

18 Para. 278, Merits Award.

19 C. Schofield, J.R.V. Prescott \& R. van der Poll, An Appraisal of the Geographical Characteristics and Status of Certain Insular Features in the South China Sea, Annex 513, Merits Award. 
12 nautical miles of the high-tide features at Gaven Reef (North) and Namyit Island, and that Subi Reef lies within 12 nautical miles of the high-tide feature of Sandy Cay on the reefs to the west of Thitu. ${ }^{20}$

The Tribunal then addressed the maritime entitlement of some maritime features in SCS by applying Article 121 of UNCLOS. The legal regime of maritime features has long been a subject of controversy due to the ambiguity of the wording of Article 121 as well as diverse State practices. In this case, the Tribunal takes a decisive approach in providing a comprehensive interpretation. The Tribunal has interpreted all the words and phrases contained in Article 121(3), namely "rocks", "cannot", "sustain", "human habitation", "or", "economic life of their own" based on their ordinary meaning. It also clarified the context of Article 121(3) in relation with the object and purpose of UNCLOS and the travaux préparatoires of the Convention and stated that Article 121(3) serves as a limitation to prevent the expanded jurisdiction of the EEZ from rocks going too far. Overall, through 76 paragraphs, the Tribunal made nine important conclusions on the interpretation of Article 121(3). Among them, the most two important points are (i) the status of a feature is to be determined on the basis of its natural capacity, without external additions or modifications intended to increase its capacity to sustain human habitation or an economic life of its own and (ii) the determination of the objective capacity of a feature is not dependent on any prior decision on sovereignty. ${ }^{21}$ The Tribunal also further finds the support for its interpretation from relevant State practice. ${ }^{22} \mathrm{Ap}-$ plying such interpretation to the original, natural and geographical conditions of the Spratlys, the Tribunal concluded that none of the high-tide features in the Spratly Islands, including Itu Aba, can generate entitlements to an EEZ or continental shelf. ${ }^{23}$ The Tribunal also clarified that the Spratlys cannot be treated as an archipelago and from which to draw straight baselines. ${ }^{24}$

As to the activities conducted by China in the scs, the Tribunal held five important conclusions. First, the Tribunal determined that China has violated the sovereign rights and jurisdiction of the Philippines over its EEZ and continental shelf by interfering with the Philippines' petroleum exploration and seismic survey at the Reed Bank, applying the 2012 moratorium on fishing in the area north of $12^{\circ} \mathrm{N}$ latitude and through the Hainan Regulation, preventing fishing by Philippine vessels at Mischief Reef and Second Thomas Shoal and

\footnotetext{
20 Paras. $382-384$, Merits Award.

21 Para. 551, Merits Award.

22 Paras. 552-553, Merits Award.

23 Para. 646, Merits Award.

24 Paras. 573-576, Merits AwArd.
} 
constructing installations and artificial islands at Mischief Reef without the authorization of the Philippines. ${ }^{25}$ Through the operation of its marine surveillance vessels in tolerating and failing to exercise due diligence to prevent fishing by Chinese flagged vessels at Mischief Reef and Second Thomas Shoal, China also failed to exhibit due regard for the Philippines' sovereign rights with respect to fisheries in its EEz. ${ }^{26}$ The conclusion of the Tribunal based on the earlier rejection of any maritime entitlement of the nine-dashed line as well as the limited maritime entitlement of the maritime features of the Spratlys. Accordingly, as both Mischief Reef and Second Thomas Shoal are located within 200 nautical miles of the Philippines' coast on the island of Palawan and are located in an area that is not overlapped by the entitlements generated by any maritime feature claimed by China, between the Philippines and China, Mischief Reef and Second Thomas Shoal form part of the EEZ and continental shelf of the Philippines. ${ }^{27}$

Second, the Tribunal held that China, through the operation of its official vessels at Scarborough Shoal from May 2012 onwards, failed to respect the traditional fishing rights of Philippine fishermen. ${ }^{28}$ The conclusion given was based on the recognition that Scarborough Shoal has been a traditional fishing ground for many nations, including the Philippines, China (including Taiwan) and Vietnam. ${ }^{29}$

Third, the Tribunal confirms that China, through its toleration and protection of, and failure to prevent Chinese fishing vessels engaging in harmful harvesting activities of endangered species at Scarborough Shoal, Second Thomas Shoal and other features in the Spratly Islands as well as its islandbuilding activities at Cuarteron Reef, Fiery Cross Reef, Gaven Reef (North), Johnson Reef, Hughes Reef, Subi Reef and Mischief Reef, violated its obligation concering protection and preservaton of the marine environment. ${ }^{30}$

Fourth, the Tribunal stated that China, by virtue of the conduct of Chinese law enforcement vessels in the vicinity of Scarborough Shoal, created serious risk of collision and danger to Philippine vessels and personnel, violated its obligation to maintain safety at sea. ${ }^{31}$

Finally, the Tribunal found that China, in the course of the arbitral proceedings, aggravated and extended the disputes between the parties concerning

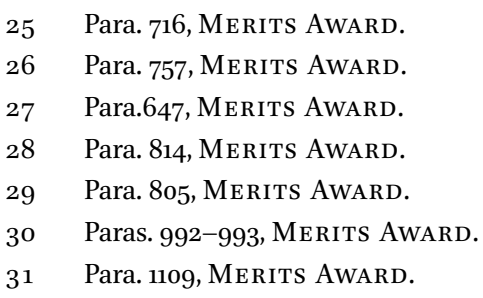


maritime entitlement at Michief Reef, as well as the legal status of maritime features and its marine environmental protection obligations through its dredging, artificial island-building, and construction activities. ${ }^{32}$

\section{Implications on the Scope of the scs Disputes}

The scs disputes consist of two layers: (1) territorial disputes over sovereignty of maritime features and (ii) maritime disputes over maritime entitlements and rights. The awards in the scs arbitration case, although binding only upon the parties to the case, i.e. the Philippines and China, produce significant implication in limiting the scope of the scs disputes.

Parties to the disputes in the scs lodge various sovereignty claims over the maritime features in the scs. Vietnam claimed the whole Paracels and Spratlys by an official statement made by its protectorate, France, in $1933,{ }^{33}$ then by the official Declaration of South Vietnam at the San Francisco Conference of $1951,{ }^{34}$ and the official statements made by the united Vietnam since $1975 \cdot{ }^{35}$ China made the first offical claim over the Paracels, Spratlys and Macclesfield Bank (which is said to include Scarbrough) in $195^{1}$ through the statement of the Foreign Minister of the People's Republic of China, Zhou Enlai. ${ }^{36}$ The Philippines claimed sovereignty over the Kalayaan Island Group (a large number of features in the Spratlys) by the issuance of Presidental Decree No. 1956 on 11 June $1978^{37}$ and Panatag (Scarborough) Shoal on the basis of State practice of Spain during the colonial period. ${ }^{38}$ Malaysia claimed several maritime

32 Para. 1181, Merits Award.

33 For full text of the French statement see OfFicial Journal of THE RePublic of FrANCE, 26 July 1933, 7837 .

34 Letter dated 3 July 2014 from the Permanent Representative of Vietnam to the United Nations addressed to the Secretary-General of the United Nation, UN documents, A/68/942, available at <http://undocs.org/A/68/942>.

35 Ibid

36 Para 33 of the Paper entitled China Adheres to the Position of Settling Through Negotiation the Relevant Disputes Between China and the Philippines, issued on 13 July 2016, available at <http://www.fmprc.gov.cn/mfa_eng/zxxx_662805/t1380615.shtml>.

37 Presidential Decree Number 1596, full text available at <http://www.gov.ph/1978/ o6/11/presidential-decree-no-1596-s-1978/>.

38 Philippine position on Bajo de Masinloc (Scarborough Shoal) and the WaTERS WITHIN ITS VICINITY, 18 April 2012, full text available at: < http://www.gov.ph/2012/ 04/18/philippine-position-on-bajo-de-masinloc-and-the-waters-within-its-vicinity/> 
features of the Spratlys based on the continental shelf map of $1979 .{ }^{39}$ Brunei also used a map on the EEZ and continental shelf published in 1987 and 1988 to claim sovereignty over Louisa Reef. ${ }^{40}$ All parties, nevertheless, have not yet clarified the legal status of claimed maritime features. All claims, except those of Brunei, was made to groups of features and it seems that there is neither distinction made for sovereignty over high tide or low tide features. This is confirmed by Chinese straight baselines drawn over the Paracels similar to archipelagic baselines method, ${ }^{41}$ oath taking ceremony at James Shoal (a low tide elevation) and construction building on Mischief Reef (a low tide elevation concluded by the scs arbitration that is located on the continental shelf of the Philippines), etc. These practices show that claimants in the SCS lodge sovereignty claims over both low tide and high tide features as well as the waters between the features.

The scs Award, echoed the conclusions of previous judgment and affirmed that low tide elevations are not subject to sovereignty claims. It stated that "[n] otwithstanding the use of the term 'land' in the physical description of a lowtide elevation, such low-tide elevations do not form part of the land territory of a State in the legal sense. Rather they form part of the submerged landmass of the State and fall within the legal regimes for the territorial sea or continental shelf, as the case may be. Accordingly, and as distinct from land territory, the Tribunal subscribes to the view that low-tide elevations cannot be appropriated, although 'a coastal State has sovereignty over low-tide elevations which are situated within its territorial sea, since it has sovereignty over the territorial sea itself." ${ }^{\prime 2}$ In the possibility of treating the maritime features as a group and drawing archipelagic baselines, the Tribunal takes a clear view that any application of straight baselines to the Spratly Islands in this fashion would be contrary to UNCLOS. ${ }^{43}$ This conclusion is made based on the interpretation of Article 7 of UNCLOS on the application of straight baselines, in cross reference

39 The map was published under the name of Peta Baru and supported by no official sovereignty statement. For further, see Asri Salleh, Che Hamdan Che Mohd Razali and Kamaruzaman Jusoff, Malaysia's policy towards its 1963-2008 territorial disputes, 1(5) Journal of LAW AND Conflict Resolution 107 (2009) 111-113.

40 Similar to Malaysia's claim, the map has not been supported by official sovereignty statement. For further information, see Daniel J. Dzurek, The Spratlys Island Dispute: Who's on first? 2(1) MARITIME BRIEFING (1996) 22.

41 Declaration of the Government of the People's Republic of China on the BASELINES OF THE TERritorial SEA, 15 May 1996, available at http://www.un.org/ Depts/los/LEGISLATIONANDTREATIES/PDFFILES/CHN_1996_Declaration.pdf.

42 Para. 309, Merits AWARD.

43 Para. 577, Merits Award. 
with Articles 46 and 47 on archipelagic baselines. The Tribunal also examined relevant State practices and held that " $[\mathrm{n}]$ otwithstanding the practice of some States to the contrary, the Tribunal sees no evidence that any deviations from this rule have amounted to the formation of a new rule of customary international law that would permit a departure from the express provisions of the Convention." 44

The two important conclusions of the Tribunal on the legal status of low tide elevations and the impossibility of drawing archipelagic baselines for the whole Spratlys indicates that at least between China and the Philippines, the scope of sovereignty disputes has been significantly reduced. For example, Mischief Reef, Second Thomas Shoal and Reed Bank are no longer subject to sovereignty disputes between China and the Philippines. The Tribunal made a firm conclusion that they belong to the continental shelf of the Philippines. If this approach is followed by other claimants, the scope of the sovereignty disputes in the SCS, accordingly will be narrowed to only high tide features and low tide features which are located within 12 nautical miles of the high tide features. Other low tide elevations located beyond 12 nautical miles off a coast will be freed from disputes, their fates will be decided according to the legal regime of the respective seabed where they are located.

In terms of maritime disputes, the disagreements in the scs come from three different maritime entitlements generated from the main coastlines of the littoral States, maritime features and the nine-dashed line. First, maritime zones generated from the coastlines of littoral States in accordance with UNCLOS may create overlapping maritime jurisdictional entitlements due to the adjacent and opposite locations of relevant States. These overlaps, after the Award, remain the same as these are outside the jurisdiction of the Tribunal and the Tribunal is unable to address maritime delimitation.

The second is the maritime zone generated from the mid-ocean maritime features in the SCS, of which, due to their geographical locations, if such belong to one country, may lead to significant overlapping with other littoral States. China, in fact, claims not only the sovereignty over the whole of the Spratlys, but also the EEZ and continental shelf for this group. ${ }^{45}$ This leads to a series of incidents in the SCS in asserting sovereignty, sovereign rights and jurisdictions, including, for example, the severing of towed cables attached to Vietnamese

44 Para. 576, Merits Award.

45 Note Verbale from the People's Republic of China to the Secretary-GenERAL of the United NAtions, No. CML/8/2011 (14 April 2011), available at: http:// www.un.org/depts/los/clcs_new/submissions_files/mysvnm33_09/chn_2011_re_phl_ e.pdf. 
survey ships by Chinese vessels and the encounter between China and the Philippines at Reed Bank in 2011, the opening of nine oil blocks in Vietnam's EEz for bidding by a Chinese State oil company and the Scarborough standoff in 2012, the deployment of the Chinese drilling vessel HYsY-981 into Vietnam's EEZ and Chinese oath taking at James Shoal in 2014, and frequent fishing incidents, etc. The Tribunal also clarified that all of the high tide features of the Spratlys have no EEZ or continental shelf. This approach may apply by analogy to the Paracels, a similar group with the Spratlys in terms of geography and historical usage. As a result, maritime disputes generated by the maritime features in the SCS will be significantly reduced and confined within 12 nautical miles of the high tide features.

The third maritime entitlement from the nine-dashed line has never been fully clarified by China, but could be some kind of "sovereignty over adjacent waters and sovereign right and jurisdiction over relevant waters" 46 or "rights and relevant claims over the SCS ... formed in the long course of history."47 This may result in up to $80 \%$ of the maritime zones in the scs to be in dispute. In the Merits Award, the Tribunal clearly denied the possibility of using the ninedashed line to generate historic rights, or other sovereign rights or jurisdiction

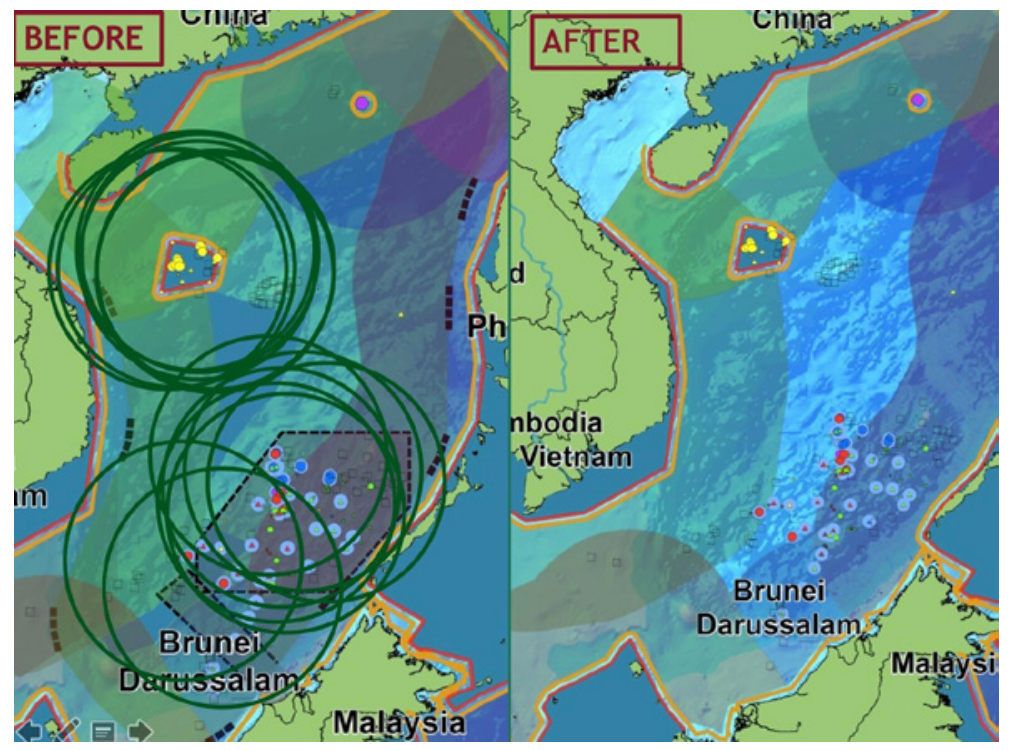

46 Para. 2, Notes Verbale of China, 7 May 2009. The attached map was the nine-dashed line map.

47 Foreign Ministry Spokesperson Jiang Yu's Regular Press Conference on 15 September 2011 http://www.fmprc.gov.cn/eng/xwfw/s2510/t86o126.htm. 
in the scs. This means the nine-dashed line will no longer be a source of maritime disputes in the scs.

Permanently removing the source of maritime disputes from the ninedashed line, limiting the maritime entitlement from the maritime features, the Tribunal Awards have drawn a much simpler and brighter picture for the scs where the scope of maritime disputes has been significantly reduced as follows:

\section{Implications on the scs Dispute Management and Settlement}

The case is an opportunity for the parties in the sCs disputes to review all available dispute settlement mechanisms. As between China and the Philippines, the Tribunal reviewed the application of the dispute settlement mechanism provided under various treaties, including the TAC, DOC, the UN Charter, as well as other bilateral and multilateral statements. The provisions of these treaties and documents clearly indicate that China, the Philippines and other parties to the scs adhere to the principle of settlement of disputes by peaceful means.

The TAC provides that "in case disputes on matters directly affecting [the parties] should arise, especially disputes likely to disturb regional peace and harmony, they shall refrain from the threat or use of force and shall at all times settle such disputes among themselves through friendly negotiations." ${ }^{48}$ It further stipulates that " $[\mathrm{n}]$ othing in this Treaty shall preclude recourse to the modes of peaceful settlement contained in Article 33(1) of the Charter of the United Nations. The High Contracting Parties which are parties to a dispute should be encouraged to take initiatives to solve it by friendly negotiations before resorting to the other procedures provided for in the Charter of the United Nations." 49 The Doc also confirms that "[t]he Parties concerned undertake to resolve their territorial and jurisdictional disputes by peaceful means, without resorting to the threat or use of force, through friendly consultations and negotiations by sovereign States directly concerned, in accordance with universally recognized principles of international law, including the 1982 UN Convention on the Law of the Sea." 50 This means that despite the favourable emphasis on negotiation, the parties are still open for any peaceful settlement means, including those from judicial processes. Along this line, in the Awards, the Tribunal also confirms that the provisions from relevant treaties and statements

$\begin{array}{ll}48 & \text { Article 13, TAC. } \\ 49 & \text { Article 17, TAC. } \\ 50 & \text { Para. 4, DOC. }\end{array}$


do not create a binding agreement between the parties to solely settle the SCS disputes through negotiation. They neither exclude the application of the dispute settlement mechanism provided for under Part XV of UNCLOS. ${ }^{51}$

Under Part XV of UNCLOS, the parties must follow the general provisions of Section 1. Accordingly, exchange of view is a precondition in order to invoke the compulsory procedures under Section 2 . The Awards made significant clarifications on the fulfilment of such obligations. The Tribunal quoted the dictum in Chagos Marine Protection Area ${ }^{52}$ and Artic Sunrise ${ }^{53}$ cases to specify that Article 283 of UNCLOS requires an exchange of view on the means by which the Parties' dispute will be settled and that this obligation is met. An exchange of view in this context does not require negotiations with regard to the subject-matter of the disputes. ${ }^{54}$

Before the case between the Philippines and China, another country in the region already invoked the procedures of Part XV of UNCLOS. Malaysia on 4 July 2003 unilaterally submitted a case concerning land reclamation by Singapore in and around the Straits of Johor. During the proceeding, Malaysia also made a request for provisional measure by the International Tribunal for the Law of the Sea (ITLOS). The case later ended in September 2005 by an award recognizing the settlement agreement reached by the parties. In the case between Philippines and China, the Tribunal not only endorsed the dispute settlement mechanism provided for under Part XV of UNCLOS as an alternative for peaceful settlement of the parties concerned but also concluded that the arbitral tribunal established under Annex VII of UNCLOS had jurisdiction over most of the submissions of the Philippines. These practices suggest that dispute settlement mechanism under UNCLOS serves as a feasible means for the parties to settle certain aspects of the SCS disputes. Given the complexity of the disputes and the current deadlock in negotiations, the success of the land reclamation case between Malaysia and Singapore and the arbitration between Philippines and China show the effectiveness of the dispute settlement system with the purpose to uphold international law $^{55}$ and open an alternative for the parties in their attempts to settle the scs disputes through peaceful means.

51 Paras. 212-229, 241-251, 265-296, 281-289, 299-302, 307-310, and 317-321, JURISDICTION AWARD.

$5^{2}$ The Chagos Marine Protected Area Arbitration (Mauritius v. United Kingdom), 2015, available at $<$ http://www.pcacases.com/web/view/11>.

53 The Arctic Sunrise Arbitration (the Netherlands v. the Russian Federation), 2015, available at $<$ http://www.pcacases.com/web/view/21> (accessed on 10 November 2016).

54 Paras. 332-352, Jurisdiction AwARd.

55 Yoshifumi Tanaka, Reflections on the Philippines/China Arbitration: Award on Jurisdiction and Admissibility, 15 The LaW and Practice of International Courts and Tribunals 305 (2016) 325 . 
Notwithstanding significant conclusions to narrow the scs disputes and facilitate dispute settlement, the sovereignty and maritime delimitation issues remain unresolved as these two issues fall outside of the compulsory dispute settlement mechanism under UNCLOs. Pending dispute settlement, this raises the question for dispute management in the scs. At the moment, due to different interpretations and application of UNCLOS, parties to the sCs dispute impose various measures to enhance their claims. These activities are a source of further complication of the disputes and threats to marine environment protection and preservation, safety of navigation and good order at sea. The Award on the merits, in the way it examined the legality of various activities of China in the scs, has provided legal basis for the conduct of parties in the scs. Accordingly, as the nine-dashed line cannot be used for maritime claims and the maritime features of the Spratlys can only generate limited maritime entitlement, activities of one State conducted within the EEZ and continental shelf of other littoral States, generated from their mainland, will constitute violations of UNCLOS. This may facilitate the process of building of a list of what activities are permitted and which ones are prohibited, an important matter in the drafting a code of conduct for the parties in the scs.

Moving beyond activities which are considered legal within the maritime zones, the Award addressed two other important aspects regarding the marine environment protection and safety of navigation. As to the marine environment, the Tribunal sought assistance from expert reports, ${ }^{56}$ which provide a factual picture of current devastation and damage of the marine environment and the cause of such a situation in the scs. The preservation of the marine environment is further highlighted as an international obligation regardless the legal regime of maritime zones. The Award provides a harmonised application of such obligation from provisions of UNCLOS, CBD, CITES and FAO Code of Conduct for Responsible Fisheries. ${ }^{57}$ The considerations of the Tribunal, therefore, pave the way for cooperation and management for marine environment

56 Dr. rer. Nat. Sebastian C.A. Ferse, Professor Peter Mumby, PhD and Dr. Selina Ward, PhD, Assessment of the Potential Environmental Consequences of Construction Activities on Seven Reefs in the Spratly Islands in the South China Sea (26 April 2016) (referred as Ferse Report), Professor John W. McManus, Offshore Coral Reef Damage, Overfishing and Paths to Peace in the South China Sea (rev. ed., 21 April 2016) (referred as McManus Report), Professor Camilo Mora, Dr. Iain R. Caldwell, Professor Charles Birkeland, and Professor John W. McManus, "Dredging in the Spratly Islands: Gaining Land but Losing Reefs, 14(3) PLoS Biology (31 March 2016) (referred as Mora Report), Professor Kent E. Carpenter, Eastern South China Sea Environmental Disturbances and Irresponsible Fishing Practices and their Effects on Coral Reefs and Fisheries (22 March 2014) (referred as Carpenter Report).

Paras. 939-996. Merits AwArd. 
protection and preservation in the scs. This becomes a more urgent need given the rich biodiversity and marine environment of a semi-enclosed sea like the SCS.

Regarding safety of navigation, at the moment, due to the competing claims, vessels from different forces, including law enforcement, navy as well as private sectors operate within the narrow sea of the Scs, which pose a high risk for safety of navigation. Reports from experts providing assistance to the Tribunal during the arbitral proceedings confirm this risk. ${ }^{58}$ The conclusions of the Tribunal on this issue affirm that operation of law enforcement vessels in a dangerous manner constitute a violation of the obligation provided for under UNCLOS and the Convention on the International Regulations for Prevention of Collisions at Sea (COLREgS). The situation in the sCS and the conclusions of the Tribunal stress the need for cooperation for safety of navigation in the scs. For example, an initiative for expanding the application of the Code for Unplanned Encounters at Sea (CUEs) to law enforcement vessels is under discussion for its application in the scs.

In addition, the conclusions of the Tribunal on the maritime entitlement of maritime features of the Spratlys as well as the nine-dashed line reveal that the high sea and international seabed likely exist in the scs. This possibility also further facilitates other sea users to enjoy mare liberum freedom of navigation, overflight, commerce and fisheries. ${ }^{59}$ It also raises the need for cooperation to preserve the freedom of the high seas as well as coordinate with the International Seabed Authority to manage the exploration and exploitation of the resources in the deep seabed of the scs.

\section{Conclusion}

With more than 700 pages, the two awards of the Arbitral Tribunal established in accordance with Annex VII of UNCLOS in the case between Philippines and China mark the first successful attempt of using a judicial measure to settle certain aspects of the scs disputes. Upon the submission of the Philippines on January 2013, the Tribunal bifurcated the arbitral proceeding to address the procedural and merit aspects of the case. The statements of the Tribunal

$5^{8}$ Allen Report, Captain Gurpreet S. Singhota, Report of the International Navigational Safety Expert appointed by the Permanent Court of Arbitration, The Hague, The Netherlands (15 April 2016).

59 George K. Ndi, Philippines $v$ China: assessing the implications of the South China Sea arbitration, Australian Journal of Maritime \& OCean AfFairs (2016) 14. 
on jurisdiction and admissibility provide a positive confirmation on jurisdiction of the Tribunal, thereby, prove that judicial method can be used as a feasible solution facilitating dispute settlement in the scs. On the merits of the case, the conclusions of the Tribunal produced significant impacts on freeing the majority of the maritime spaces in the scs from disputes. Relying on the awards, the parties possess firm legal basis to clarify the scope of sovereignty and maritime disputes in the scs disputes. The reasoning of the Tribunal also provided a guideline for the conduct of the parties in the SCs, which will facilitate the process of management of the disputes and foster cooperation for marine environment protection and safety of navigation. The arbitrators have completed their roles producing a landmark award for the SCS and the result has opened new chapters, creating a new legal status quo in the SCs. It is now up to the parties to seize the given opportunities to turn a hotspot into a sea of cooperation based on good faith and the rule of law. 